\title{
Apoptosis-, proliferation, immune function-, and drug resistance- related genes in ER positive, HER2 positive and triple negative breast cancer
}

\author{
A. KOLACINSKA ${ }^{1, *}$, J. CHALUBINSKA ${ }^{2}$, I. ZAWLIK ${ }^{3}$, B. SZYMANSKA ${ }^{4}$, E. BOROWSKA-GARGANISZ ${ }^{5}$, M. NOWIK ${ }^{5}$, W. FENDLER ${ }^{6}$, R. KUBIAK$^{7}$, \\ Z. PAWLOWSKA ${ }^{4}$, Z. MORAWIEC ${ }^{1}$, J. SZEMRAJ ${ }^{8}$
}

\begin{abstract}
${ }^{1}$ Department of Surgical Oncology, Cancer Center, Copernicus Memorial Hospital, Lodz, Poland; ${ }^{2}$ Department of Radiotherapy, Cancer Center, Copernicus Memorial Hospital, Medical University of Lodz, Poland; ${ }^{3}$ Department of Molecular Pathology and Neuropathology, Medical University of Lodz, Poland; ${ }^{4}$ Central Laboratory, Medical University of Lodz, Poland; ${ }^{5}$ Department of Radiology, Cancer Center, Copernicus Memorial Hospital, Lodz, Poland; ' Department of Pediatrics, Oncology, Hematology and Diabetology, Medical University of Lodz, Poland; ${ }^{7}$ Department of Pathology, Medical University of Lodz, Poland; ${ }^{8}$ Department of Medical Biochemistry, Medical University of Lodz, Poland
\end{abstract}

*Correspondence: agnkol@gazeta.pl,info@drkolacinska.pl

Received November 2, 2011 / Accepted February 17, 2012

\begin{abstract}
The aim of our study was to examine an association between gene expression assessed using a 23-gene microarray and receptor status of breast cancer samples categorized as ER positive, HER2 positive and triple negative subtypes. The ER positive cohort was subsequently divided into Luminal A, Luminal B HER2 negative and Luminal B HER2 positive subtypes. Core- needle biopsies were collected from 78 female patients with inoperable locally advanced breast cancer or resectable tumors suitable for downstaging, before any treatment. Expressions of 23 genes were determined by means of TagMan Low Density Arrays. Analysis of variance was used to select genes with discriminatory potential between receptor subtypes. We introduced a correction for false discovery rates (presented as q values) due to testing multiple hypothesis. Pairwise post-hoc comparisons of receptor subtypes were performed using Tukey 's HSD test. Five genes out of a 23-gene microarray differed significantly in relation to breast cancer receptor-based subtypes. Among these five genes, we identified: $B C L 2$ ( $\mathrm{p}=0.0002$, $\mathrm{q}=0.0009), \operatorname{MKI67}(\mathrm{p}=0.0037, \mathrm{q}=0.0064), \operatorname{IGF} 1 R(\mathrm{p}=0.0040, \mathrm{q}=0.0064), F O X C 1(\mathrm{p}=0.0113, \mathrm{q}=0.0135)$ and $I R F 1(\mathrm{p}=0.0435$, $\mathrm{q}=0.0416$ ) as ones showing ER positive, HER2 positive and triple negative -subtype specific expression profiles. When incorporating Luminal A, Luminal B HER2 negative, Luminal B HER2 positive subtypes into analysis, four genes: $B C L 2$ $(\mathrm{p}=0.0006, \mathrm{q}=0.0034), \operatorname{MKI67}(\mathrm{p}=0.0078, \mathrm{q}=0.0198), F O X C 1(\mathrm{p}=0.0102, \mathrm{q}=0.0198)$ and $I G F 1 R(\mathrm{p}=0.0174, \mathrm{q}=0.0254)$ were selected. Elevated levels of $I G F 1 R$ and BCL2 were significantly linked with Luminal A subtype. Triple negative breast cancer subtype was associated with higher expression of IRF1, FOXC1 and MKI67. In HER2 positive cohort lower expression of all five analyzed genes was noted.
\end{abstract}

Key words: breast cancer, gene microarray, receptor subtypes

Heterogeneity of breast cancer is a well established phenomenon [1-3] but is not adequately reflected by traditional clinical and pathological criteria such as tumor size, node involvement, grade, estrogen receptor (ER), progesterone receptor $(\mathrm{PR})$ and human epidermal growth factor receptor 2 (HER2) status [4-6]. In recent years, genetic developments and other more sophisticated methods of characterization of breast cancer have evolved [4, 7-9]. In addition to the three receptor-based subtypes - ER positive, HER2 positive and triple negative, intrinsic subtypes of breast cancer have been identified in recent years - Luminal A, Luminal B, HER2enriched, Basal-like and their clinico-pathologic definition classified as Luminal A, Luminal B HER2 negative, Luminal B HER2 positive, HER2 positive (non luminal) and triple negative (ductal) $[4,8,10,11]$. Furthermore, a wide variety of multigene signatures have been validated to individualize decision making and therapeutic algorithms. Extensive research has been conducted on pathways that involve proliferation and apoptosis cascades, immune response genes, chemo- and endocrine response and resistance (the 70-gene signature Mammaprint ${ }^{\mathrm{m}}$, the 21-gene signature Oncotype $\mathrm{DX}^{\mathrm{TN}}$, Femtelle ${ }^{\mathrm{TN}}$, 76-gene signature, Core epithelial-to-mesenchymal transition interactome gene-expression signature, the 7 gene immune response, wound response gene signature, 
MapQuant ${ }^{\text {tM }}$ Genomic Grade, an anthracycline- based score A-score, etc) [12-22]. The majority of these signatures show comparable performance despite the limited overlap of genes, but are probably less informative for ER negative patients [23], leaving scope for further research.

The aim of our study was to examine an association between 23-gene microarray including $A B C B 1, A B C C 1, B A X, B B C 3$, BCL2, CASP3, CYP2D6, ERCC1, FOXC1, GAPDH, IGF1R, IRF1, MAP2, MAPK 8, MAPK9, MKI67, MMP9, NCOA3, PARP1, PIK3CA, TGFB3, TOP2A, YWHAZ (Table 1) with receptor status of breast cancer samples categorized as ER positive, HER2 positive and triple negative subtypes. The ER positive cohort was subsequently divided into Luminal A, Luminal B HER2 negative and Luminal B HER2 positive subtypes. Lists of genes that represent various biological pathways were assembled from gene datasets [24, 25].

\section{Patients and methods}

The study was conducted under Institutional Review Board protocol \# RNN/159/10/KE/07/09/2010, Medical University of Lodz and all patients gave written informed consent.

Before any treatment, ultrasound guided 14-gauge coreneedle biopsies using an ultra automatic biopsy instrument (Pro-Mag ${ }^{\mathrm{Tm}}$, Angiotech) were collected from 78 female patients with inoperable locally advanced breast cancer or resectable tumors suitable for downstaging, and from two healthy controls at the Cancer Center of Lodz, Copernicus Memorial Hospital between September 2010 and April 2011. Four to - five specimens per lesion were obtained, half of which were frozen immediately at $-80{ }^{\circ} \mathrm{C}$, for subsequent RNA extraction, cDNA generation and custom-designed TaqManR gene expression assay. The other samples were paraffin-embedded and reviewed by dedicated breast pathologists in the Department of Pathology, Medical University of Lodz. ER and PR status were determined by immunohistochemistry (IHC) using the Allred score. HER2 status was evaluated by immunohistochemistry or by fluorescence in - situ hybridization. HER2-positive tumors were defined as 3+ receptor overexpression on IHC staining and/or gene amplification found on fluorescent in - situ hybridization. TNM clinical staging was assessed by mammography, ultrasound of the breast, axilla and abdomen, and chest $\mathrm{x}$-ray. In selected cases, MRI of the breast was performed.

Total RNA extraction and cDNA generation. Total RNA was extracted from samples according to the manufacturer 's RNeasy mini kits protocol (Qiagen, Hilden, Germany). In the initial step, RLT buffer (containing $\beta$-mercaptoethanol) was added to Eppendorf tubes containing the frozen samples which were homogenized using a Qiagen homogenizer (TissueRuptor) and centrifuged for $3 \mathrm{~min}$ at $14000 \mathrm{rpm}$. Following the manufacturer 's protocol, a DNase digestion was performed and RNA was quantified using PicoDrop spectrophotometer (Picodrop, Saffon Walden, Cambridgeshire, UK). The quality of RNA samples was analyzed by measuring the ratio of ab- sorptions at 260/280 $\mathrm{nm}$ (an optical density ratio was between 1.9-2.2). The purified total RNA was immediately used for cDNA synthesis or stored at $-80^{\circ} \mathrm{C}$.

Generation of cDNA was performed with High Capacity cDNA Reverse Transcription Kits (Applied Biosystems Inc., Foster City, CA, USA) following the reverse transcription protocols of the manufacturer. $500 \mathrm{ng}$ of DNAse-treated total RNA was used as starting material, to which was added $2 \mathrm{x}$ RT master mix containing $2 \mu \mathrm{l}$ of 10x RT Buffer, $0.8 \mu \mathrm{l}$ of $25 \mathrm{x}$ dNTP Mix (100 mM), $2 \mu \mathrm{l}$ of 10x RT Random Primers, $1 \mu \mathrm{l}$ MultiScribe ${ }^{\mathrm{rm}}$ Reverse Transcriptase and $1 \mu \mathrm{l}$ Rase Inhibitor per each $20 \mu \mathrm{L}$ reaction. Reverse transcription was performed in conditions optimized for use with this kit $\left(25^{\circ} \mathrm{C}\right.$ for $10 \mathrm{~min}$, $37^{\circ} \mathrm{C}$ for $120 \mathrm{~min}, 85^{\circ} \mathrm{C}$ for $\left.5 \mathrm{~min}\right)$. The samples were kept frozen at $-20^{\circ} \mathrm{C}$.

Custom-designed TaqMan ${ }^{\circledR}$ Gene Expression Assays. Gene expression was measured using custom-made TaqMan Low Density Arrays (Applied Biosystems Inc., Foster City, $\mathrm{CA})$. The assay comprised of probes selected to measure expression of 23 a priori selected genes: $A B C B 1, A B C C 1, B A X$, BBC3, BCL2, CASP3, CYP2D6, ERCC1, FOXC1, GAPDH, IGF1R, IRF1, MAP2, MAPK8, MAPK9, MKI67, MMP9, NCOA3, PARP1, PIK3CA, TGFB3, TOP2 and YWHAZ.

The microfluidic cards consisted of 8 ports with 23 different TaqMan primer pair/probe sets arrayed in duplicate in a 384-well microplate. Each well contained a gene-specific forward and reverse primer, as well as a gene-specific probe, which is labeled at the 5' position with 6FAM (reporter dye) and at the 3' position with minor groove binder/non-fluorescent quencher.

RT reactions were performed after adding 500 ng cDNA mixed with 2x TaqMan Universal PCR Master Mix (Applied Biosystems Inc., Foster City, CA, USA), loaded on the TLDA card, and analyzed by PCR on the 7900HT instrument using Applied Biosystems Sequence Detection System 2.0 software according to the manufacturer's instructions. Target gene expression data from samples was normalized using 18S RNA to compensate for variability in the amount of RNA and for exclusion of general transcriptional effects.

Molecular analyses were performed in the Department of Molecular Biology, Central Laboratory, Medical University of Lodz.

Statistical analysis. Expression ratios were computed for each gene by dividing the values obtained in each patient by those from healthy tissue samples. Gene expression data underwent logarithmic transformation and standardization by dividing their difference from group mean by respective standard deviations. This provided a homogenous group of variables with similar scales and ranges of values. Univariate comparisons of gene profile between receptor subtypes were performed using analysis of variance (ANOVA) with p values verified by false discovery rates (FDR) to correct for multiple hypotheses testing. Genes that showed different expression depending on receptor subtype in ANOVA entered post-hoc analyses with Tukey's HSD test to determine which subgroup 
Table 1. Summary of the studied genes. ${ }^{\star} 3$ subtype analysis included ER positive, HER2 positive and triple negative subtypes. ${ }^{\star *} 5$ subtype analysis included Luminal A, Luminal B HER2 negative, Luminal B HER2 positive, HER2 positive and triple negative subtypes.

\begin{tabular}{|c|c|c|c|c|c|c|}
\hline $\begin{array}{l}\text { Gene } \\
\text { symbol }\end{array}$ & Full name & Function & $\begin{array}{l}\text { p } \\
(3 \text { subtype } \\
\left.\text { analysis }^{\star}\right)\end{array}$ & $\begin{array}{l}\text { q } \\
\text { (3 subtype } \\
\left.\text { analysis }^{\star}\right)\end{array}$ & $\begin{array}{l}\text { p } \\
(5 \text { subtype } \\
\left.\text { analysis }^{* *}\right)\end{array}$ & $\begin{array}{c}\mathrm{q} \\
(5 \text { subtype } \\
\left.\text { analysis }^{\star *}\right)\end{array}$ \\
\hline \multicolumn{7}{|c|}{ Apoptosis- related genes } \\
\hline$B A X$ & $B c l-2$ associated $\mathrm{X}$ protein & Apoptotic activator & 0.1394 & 0.0707 & 0.3131 & 0.1409 \\
\hline$B B C 3$ & $\begin{array}{l}\text { PUMA- p53 upregulated modulator of } \\
\text { apoptosis; } \\
\text { Bcl-2 binding component } 3\end{array}$ & $\begin{array}{l}\text { Essential mediator of p53-dependent and p53- } \\
\text { independent apoptosis }\end{array}$ & 0.6605 & 0.1581 & 0.7469 & 0.2080 \\
\hline$B C L 2$ & B-cell CLL/Lymphoma 2 & Suppression of apoptosis & 0.0002 & 0.0009 & 0.0006 & 0.0034 \\
\hline CASP3 & $\begin{array}{l}\text { Caspase 3; apoptosis-related cysteine } \\
\text { peptidase }\end{array}$ & Execution-phase of cell apoptosis & 0.4828 & 0.1358 & 0.6955 & 0.2034 \\
\hline \multicolumn{7}{|c|}{ Proliferation- related genes } \\
\hline FOXC1 & Forkhead box $\mathrm{C} 1$ & $\begin{array}{l}\text { Embryonic and ocular development; regula- } \\
\text { tion of cellular functions in breast cancer }\end{array}$ & 0.0113 & 0.0135 & 0.0102 & 0.0198 \\
\hline IGF1R & Insulin-like growth factor 1 receptor & $\begin{array}{l}\text { Tyrosine kinase activity; anti-apoptotic agent } \\
\text { enhancing cell survival; mediates pre- and } \\
\text { postnatal growth }\end{array}$ & 0.0040 & 0.0064 & 0.0174 & 0.0254 \\
\hline MAPK8 & $\begin{array}{l}\text { Mitogen activated protein kinase 8; C-Jun } \\
\text { kinase 1; JNK1; Jun N-terminal kinase }\end{array}$ & $\begin{array}{l}\text { Response to activation by environmental stress } \\
\text { and pro-inflammatory cytokines, T-cell prolif- } \\
\text { eration, apoptosis and differentiation }\end{array}$ & 0.1388 & 0.0707 & 0.2972 & 0.1409 \\
\hline MAPK9 & $\begin{array}{l}\text { Mitogen activated protein kinase 9; C-Jun } \\
\text { kinase 2; JNK2 }\end{array}$ & $\begin{array}{l}\text { Stress- activated serine-threonine kinase, in- } \\
\text { volved in cancer and inflammation, increases } \\
\text { the stability of p53 in non-stressed cells }\end{array}$ & 0.8494 & 0.1909 & 0.5685 & 0.1750 \\
\hline MKI67 & Ki-67 & Proliferation- related antigen & 0.0037 & 0.0064 & 0.0078 & 0.0198 \\
\hline MMP9 & $\begin{array}{l}\text { Matrix metalloproteinase 9; type IV col- } \\
\text { lagenase, GELB gelatinase B }\end{array}$ & $\begin{array}{l}\text { Breakdown of extracellular matrix, tissue } \\
\text { remodeling, proliferation, migration, angio- } \\
\text { genesis, differentiation, metastasis }\end{array}$ & 0.1626 & 0.0707 & 0.1882 & 0.1376 \\
\hline TGFB3 & Transforming growth factor beta 3 & Suppression and promotion of tumorigenesis & 0.3169 & 0.1010 & 0.4742 & 0.1569 \\
\hline \multicolumn{7}{|c|}{ Immune function genes } \\
\hline IRF1 & Interferon regulatory factor 1 & $\begin{array}{l}\text { Immune function gne; apoptosis, tumor sup- } \\
\text { pression; }\end{array}$ & 0.0435 & 0.0416 & 0.1432 & 0.1376 \\
\hline \multicolumn{7}{|c|}{ Drug resistance/ metabolism - related genes } \\
\hline$A B C B 1$ & $\begin{array}{l}\text { ATP-binding cassette sub-family B mem- } \\
\text { ber } 1\end{array}$ & $\begin{array}{l}\text { Decreased drug accumulation in multidrug- } \\
\text { resistant cells; development of resistance to } \\
\text { anticancer drugs }\end{array}$ & 0.1895 & 0.0734 & 0.2152 & 0.1399 \\
\hline$A B C C 1$ & $\begin{array}{l}\text { MRP1- multidrug resistance protein; } \\
\text { ATP-binding cassette sub-family C mem- } \\
\text { ber } 1\end{array}$ & Multidrug resistance & 0.1165 & 0.0707 & 0.0623 & 0.0729 \\
\hline CYP2D6 & $\begin{array}{l}\text { Cytochrome P450, family 2, subfamily D, } \\
\text { polypeptide } 6\end{array}$ & Drug metabolism & 0.8781 & 0.1909 & 0.9590 & 0.2550 \\
\hline ERCC1 & Excision repair cross complementing 1 & DNA repair & 0.3960 & 0.1184 & 0.3385 & 0.1414 \\
\hline MAP2 & Microtubule associated protein 2 & Stabilization of microtubules & 0.1550 & 0.0707 & 0.1820 & 0.1376 \\
\hline NCOA3 & Nuclear receptor coactivator 3; AIB-1 & $\begin{array}{l}\text { Coactivation of nuclear receptors such as ster- } \\
\text { oids (ER), histone acetyltransferase activity }\end{array}$ & 0.6157 & 0.1581 & 0.4830 & 0.1569 \\
\hline PARP1 & Poly-(ADP ribose) polymerase 1 & $\begin{array}{l}\text { Base excision repair pathway, DNA me- } \\
\text { tabolism }\end{array}$ & 0.6612 & 0.1581 & 0.2805 & 0.1409 \\
\hline PIK3CA & $\begin{array}{l}\text { Phosphoinositide- } 3 \text { kinase, catalytic, } \\
\text { alpha polypeptide }\end{array}$ & $\begin{array}{l}\text { Lipid kinase, involved in proliferation, cell } \\
\text { survival and migration, cooperation with the } \\
\text { mTOR (mammalian target of rapamycin) } \\
\text { pathway }\end{array}$ & 0.2608 & 0.0891 & 0.4698 & 0.1569 \\
\hline TOP2A & Topoisomerase II alpha & $\begin{array}{l}\text { Control of topology of DNA strands; develop- } \\
\text { ment of drug resistance }\end{array}$ & 0.1599 & 0.0707 & 0.2586 & 0.1409 \\
\hline YWHAZ & $\begin{array}{l}\text { Tyrosine 3-monooxygenase/tryptophan 5- } \\
\text { monooxygenase activation protein, zet }\end{array}$ & $\begin{array}{l}\text { Anti-apoptotic gene; chemoresistance to } \\
\text { anthracyclines }\end{array}$ & 0.1996 & 0.0734 & 0.3698 & 0.1442 \\
\hline \multicolumn{7}{|c|}{ Endogenous control } \\
\hline GAPDH & $\begin{array}{l}\text { Glyceraldehyde-3-phosphate dehydro- } \\
\text { genase }\end{array}$ & $\begin{array}{l}\text { Endogenous control; carbohydrate metabo- } \\
\text { lism }\end{array}$ & & & & \\
\hline
\end{tabular}


deviated from the remainder in expression values. Statistical computations were performed in Statistica 9.0 PL (Statsoft, Tulsa, OK, USA). Hierarchical clustering of gene expression ratios was used to visualize expression patterns in the analyzed groups. The GenePattern online suite (http://genepattern. broadinstitute.org/gp/pages/index.jsf) was used for this purpose. Q values representing FDRs were computed in $\mathrm{R}$ using the qvalues package. A p value less than 0.05 was considered as statistically significant. For comparisons of gene expression profiles, a q value less than 0.05 was necessary to deem a particular result as significant rather than an incidental one due to testing multiple hypothesis.

\section{Results}

Patients enrolled in the study were aged between 32-82 years old, mean age 60.2 years. Histopathological tumor types were: invasive ductal breast cancer (67 patients), invasive lobular cancer (eight patients), mucinous cancer (one patient), adenoid cystic cancer (one patient), unknown (one patient). Tumor grades were: Gx - 1, G1 - 1, G2 - 12 and G3 - 64 patients. Tumor stage was: stage I in two patients, IIA in six, IIB in 13 , IIIA in 19 , IIIB in 25 , IIIC in four and IV in 9 individuals. Receptor status was: ER positive in 47 patients, ER negative in 31 patients, $P R$ positive in 38 patients, PR negative in 40 patients, HER2 positive in 13 patients, HER2 negative in 61 patients. In four cases HER2 status was unknown and these patients were not included in statistical analysis. Surrogates of intrinsic subtypes were: Luminal A (34 patients), Luminal B HER2 negative (7 patients), Luminal B HER2 positive (5 patients), Triple Negative (20 patients), HER2 positive (8 patients).

After neoadjuvant chemotherapy or hormonal therapy, pathologic complete response (pCR) was found in $12 \%$ of patients, near pCR- in $16.7 \%$, partial pathologic response- in $43 \%$ and no response or progression in $28.3 \%$ of patients.

Statistical analysis showed that five genes out of a 23 gene microarray differed significantly in relation to ER positive, HER2 positive, and triple negative breast cancer subtypes. Among these genes, we identified: BCL2 $(\mathrm{p}=0.0002, \mathrm{q}=0.0009), \operatorname{MKI67}(\mathrm{p}=0.0037, \mathrm{q}=0.0064), I G F 1 R$ $(\mathrm{p}=0.0040, \mathrm{q}=0.0064), F O X C 1(\mathrm{p}=0.0113, \mathrm{q}=0.0135)$ and IRF1 ( $\mathrm{p}=0.0435, \mathrm{q}=0.0416)$. Expressions of these five genes were compared between receptor subtype groups - results of these comparisons are shown in Figure 1. When incorporating Luminal A, Luminal B HER2 negative, Luminal B HER2 positive subtypes into analysis, four genes: $B C L 2(\mathrm{p}=0.0006$, $\mathrm{q}=0.0034), \operatorname{MKI} 67(\mathrm{p}=0.0078, \mathrm{q}=0.0198), F O X C 1(\mathrm{p}=0.0102$, $\mathrm{q}=0.0198)$ and $\operatorname{IGF} 1 R(\mathrm{p}=0.0174, \mathrm{q}=0.0254)$ were identified (Fig. 2).

$\mathrm{P}$ values of the remaining genes in the 23- gene microarray- ( $A B C B 1, A B C C 1, B A X, B B C 3, C A S P 3, C Y P 2 D 6, E R C C 1$, MAP2, MAPK 8, MAPK9, MMP9, NCOA3, PARP1, PIK3CA, TGFB3, TOP2A, YWHAZ) did not reach a level of statistical significance (Table 1).
Hierarchical clustering of gene expression ratios in the compared patient groups showed considerable heterogeneity of the patients categorized into the 5 subtypes of receptor status (Figure 3).

\section{Discussion}

Medical literature on Forkhead box C1 (FOXC1), initially described in eye development, is scarce $[25,26]$. Our study has demonstrated elevated FOXC1 mRNA levels in core biopsies from triple negative breast cancers. Consistently, Ray and Giuliano et al. from John Wayne Cancer Institute have shown that FOXC1 may be a pivotal prognostic biomarker of basal- like breast cancer which encompasses $60 \%$ to $90 \%$ of triple negative breast cancers $[26,27]$. On the basis of gene expression analysis of publicly available human breast cancer microarray data sets, overall survival was significantly worse in tumors with elevated FOXC1 mRNA levels and coincided with the basal- like subgroup clustered by International Genomics Consortium [26, 27]. FOXC1 is also involved in brain development and tumorigenesis which might explain why triple negative tumors more often metastasize to the brain. Ray and Giuliano et al. examined the function of FOXC1 in the breast cancer cells- elevated expression of FOXC1 in MDA-MB-231 basal-like breast cancer cells increased cell proliferation, migration and invasion [26, 27]. Taube et al. from MD Anderson Cancer Center have shown that FOXC1 induces the epithelialto-mesenchymal transition, exhibiting stem cell characteristics with metastatic potential [19].

IRF1 interferon regulatory factor 1 mediates interferon and other cytokine effects, promotes apoptosis through p53-dependent and independent pathways and caspase activation. Functionally, overexpression of IRF1 inhibited carcinogenesis in human breast cancer xenografts [25, 27]. Cavalli et al. have observed that low IRF1 mRNA expression was associated with poor clinical outcome and correlated with risk of recurrence and death [28]. These authors did not compare IRF1 levels between receptor- based subtypes. In our study, elevated IRF1 was found in triple negative breast cancers in comparison with ER positive and HER2 positive cohorts. Currently, we are correlating expressions of immune function genes with response to neoadjuvant chemotherapy in these group of patients and pathologic complete response could be a surrogate for good prognosis. Teschendorff et al. have demonstrated a positive and negative association of immune signatures with good prognosis in ER negative and ER positive disease, respectively [29]. In the studies conducted by Rody, Pusztai et al., ER(-) tumors with high expression of immune function metagenes seemed to respond better to neoadjuvant chemotherapy [30]. Furthermore, Ascierto et al. have hypothesized that a network of genes involved in B, $\mathrm{T}$ cell development, interferon signaling, and adaptive and innate immune responses, at the tumor site can predict a risk of distant relapse in breast cancer patients even regardless of the status of ER, PR or HER2 [20]. 

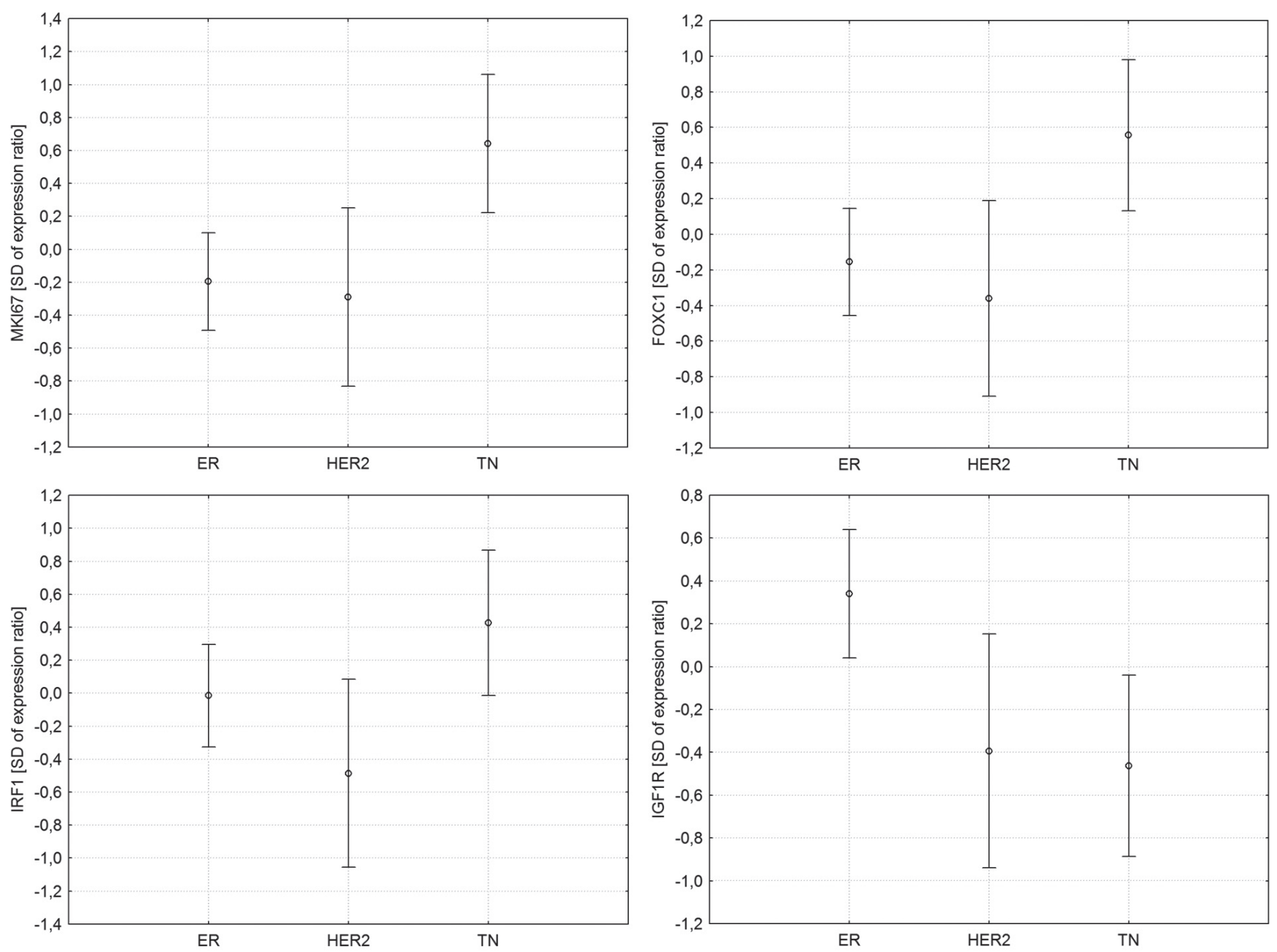

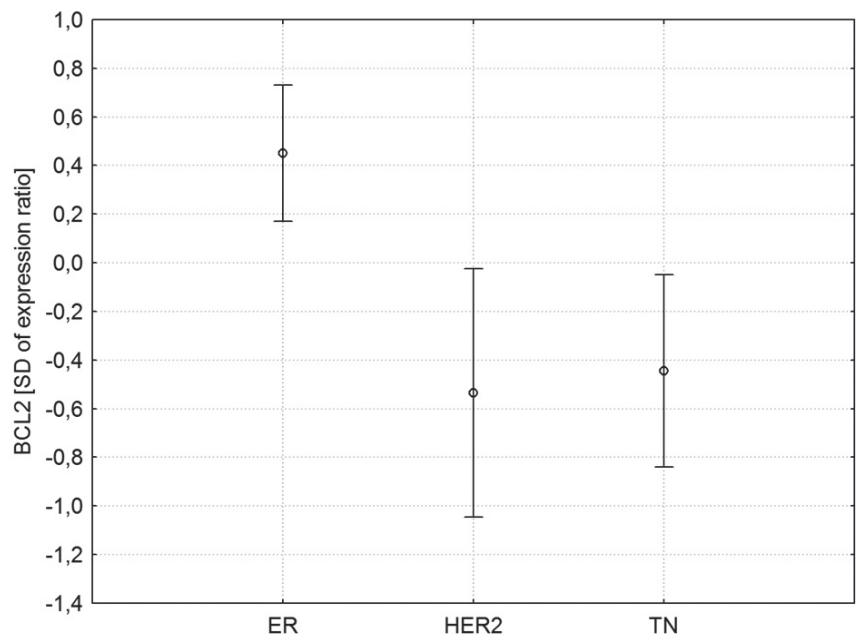

In our study expression of MKI67 - a marker of tumor cell proliferation, was significantly higher in triple negative carcinomas compared with ER positive and HER2 positive tumors, which is consistent with other research results [31,
Figure 1. Comparison of selected genes between ER positive, HER2 positive and TN subtypes. Statistically significant differences in analysis of variance were detected for MKI67, FOXC1, IRF1, IGF1R and BCL2. TN tumors were characterized by elevated $M K I 67$, FOXC1 and IRF1 levels, while ER samples showed elevated IGF1R and BCL2 levels. HER2 positive tumors did not show over or underexpression in any of the analyzed genes.

32]. In commercially available assays such as Oncotype DX, elevated MKI67 increases the recurrence score [16].

Insulin- like growth factor 1 receptor (IGF1R), with tyrosine kinase activity, mediates biologic effects of insulin- 

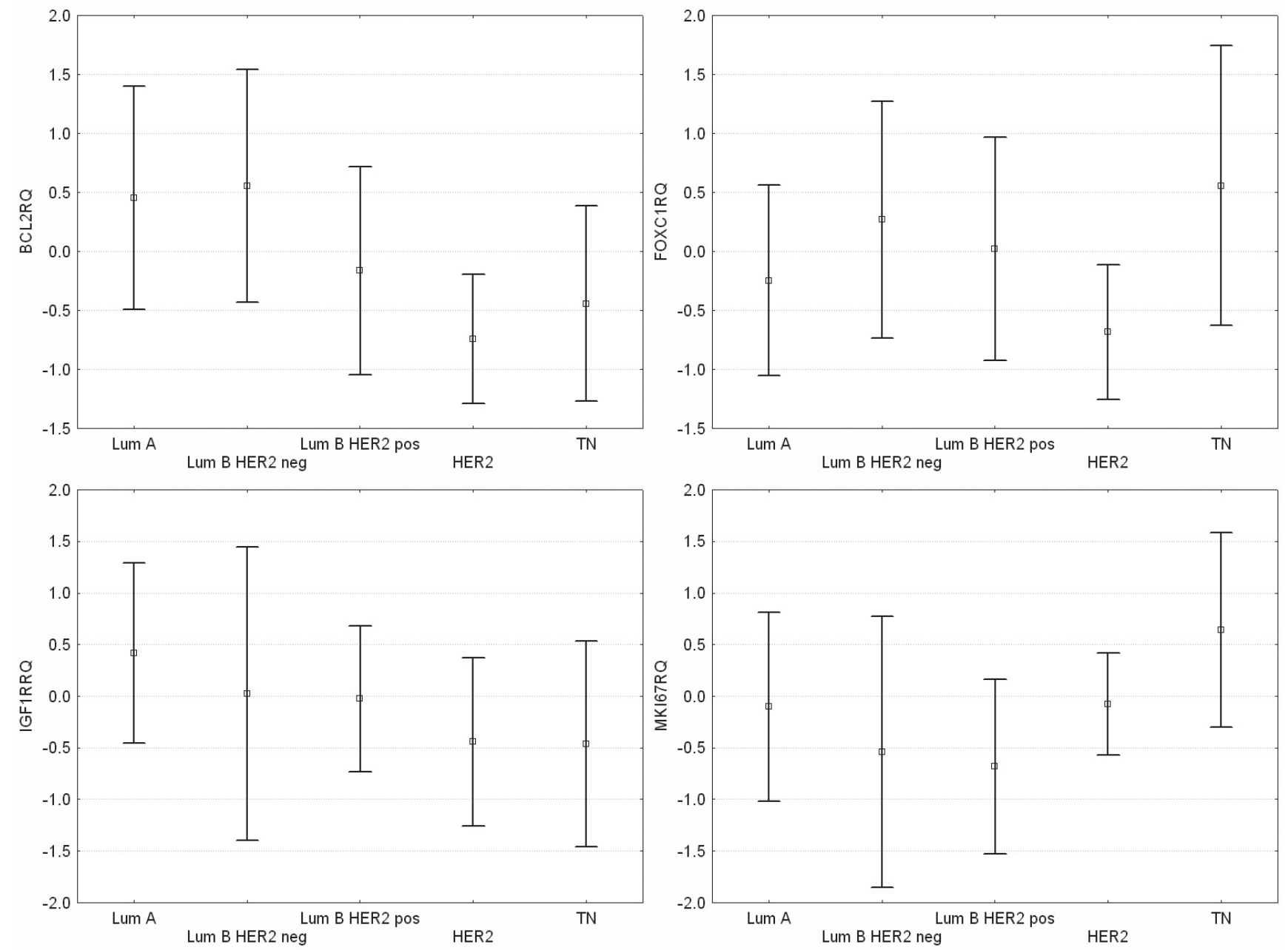

Figure 2. Comparison of selected genes between Luminal A, Luminal B HER2 negative, Luminal B HER2 positive, HER2 positive and TN subtypes. Elevated levels of BCL2 and IGF1R were a feature associated with Luminal A subtype, while elevated FOXC1 and MKI67 were observed in TN tumors.

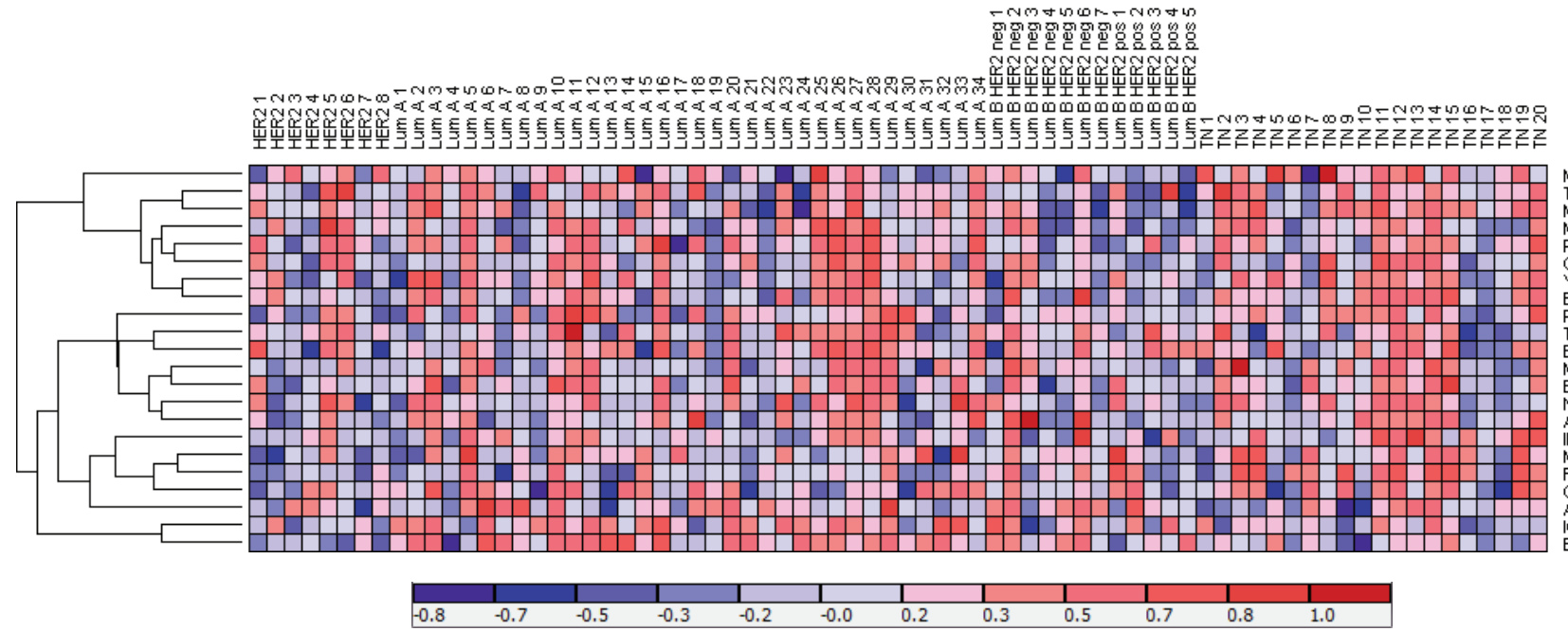

MMPSRQ OP2ARQ MAPKGRQ PARP1RQ CASP3RQ YMHAZRO PIKSCAR BBC3RQ MAPK8RQ RCCTRQ ABCC1RQ RF1RQ $M A P 2 R Q$ OXC1RQ CYP2D6RQ GF1RRQ

Figure 3. Results of hierarchical clustering of gene expression ratios (RQ). Considerable variability of expression profiles within the analyzed categories is evident, with the TN and HER2 groups being the most homogenous 
like growth factors- key factors of cell growth, survival and transformation $[24,25]$. We have shown that IGF1R mRNA levels were significantly higher in core biopsies from Luminal A tumors versus triple negative and HER2 positive carcinomas. This observation may be clinically relevant since several studies are currently ongoing with monoclonal antibodies or tyrosine kinase inhibitors directed against this target [33]. Fu et al. have demonstrated that high IGF1R status correlated with low grade, negative axillary lymph nodes, positive hormone receptor, negative HER2, lower MKI67 and luminal subtype [34]. Hartog et al. have revealed divergent effects of IGF1R expression on the prognosis of $\mathrm{ER}(+)$ cancers versus triple negative invasive ductal breast carcinoma. IGF1R expression in ER(+) tumors is strongly related to a favorable disease- free survival and breast cancer specific survival, but to a shorter survival in triple negative carcinoma [35]. Increased IGF1R mRNA levels according to intrinsic subtypes were found in 53\% of Luminal A, 24\% of Luminal B, $13 \%$ of HER2 and $10 \%$ of triple negative tumors, respectively [36]. On the basis of research on insulin/ IGF-1R, a new approach to individualized cancer therapy termed metabolo-genomics is proposed which incorporates features of both cell metabolism and gene profiling. These metabolo-genomic signatures are preferentially associated with Luminal A tumors [37, 38].

Studies on prognostic significance of BCL2 expression in triple negative versus non- triple negative breast carcinomas are limited [39]. Our findings confirmed increased expression of $B C L 2$, an anti-apoptotic, tumorigenic protein, in core biopsies from Luminal A tumors in comparison with triple negative and HER2 positive lesions, which is in accordance with data shown by Koronakis et al [40]. Other authors have shown conflicting correlations [39]. These different results in breast cancer phenotypes may be determined by the balance between the dual function of $B C L 2$ protein: inhibition of programmed cell death and initiation of cell cycle [39 ]. In future work, we intent to investigate whether $B C L 2$ is involved in resistance to hormonal therapy and chemotherapy. An association of receptor-based subtypes with gene expression shown in our study may be an essential prerequisite for further assessment of predictive markers of response to neoadjuvant chemo- or hormonal therapy in breast cancer patients.

To summarize, we conclude that elevated levels of IGF1R and BCL2 are significantly linked to Luminal A subtype. Triple negative breast cancer subtype are associated with higher expression of IRF1, FOXC1 and MKI67. In HER2 positive cohort lower levels of all these genes were found. In view of the small sample size, we need to be cautiously optimistic about presenting classification systems distinguishing between respective receptor subtypes. Initial assessment of selected gene utility in the separation of receptor subtype groups showed a $65-75 \%$ accuracy before incorporating any clinical factors into the analysis (data not shown). Further studies which focus on validation of our findings are ongoing and will attempt to include multigene signatures within the receptor- based classification in order to design targeted therapies in the genomic, proteomic, metabolomic and transcriptomic era.

Acknowledgements: This work was supported by the grant of the Ministry of Science, Poland, NN402350838.

\section{References}

[1] FISHER B, REDMOND CK, FISHER ER . Evolution of knowledge related to breast cancer heterogeneity: a 25-year retrospective. J Clin Oncol 2008; 26, 2068-71. http: //dx.doi. org/10.1200/JCO.2007.14.1804

[2] PECE S, TOSONI D, CONFALIONIERI S, MAZZAROL $\mathrm{G}$, VECCHI $\mathrm{M}$ et al. Biological and molecular heterogeneity of breast cancer correlates with their cancer stem cell content. Cell 2010; 140: 62-73. http: //dx.doi.org/10.1016/ j.cell.2009.12.007

[3] LOI S, PICCART M, SOTIRIOU C. The use of gene- expression profiling to better understand the clinical heterogeneity of estrogen receptor positive breast cancers and tamoxifen response. Crit Rev Oncol Hematol 2007; 61: 187-94. http: //dx.doi.org/10.1016/j.critrevonc.2006.09.005

[4] PRAT A, PEROU CM. Deconstructing the molecular portraits of breast cancer. Mol Oncol 2011; 5, 5-23. http: //dx.doi. org/10.1016/j.molonc.2010.11.003

[5] KNAUERM,CARDOSOF, WESSELING J, BEDARD PL, LINN SC et al. Identification of a low-risk subgroup of HER2- positive breast cancer by the 70-gene prognosis signature. Br J Cancer 2010; 103: 1788-93. http://dx.doi.org/10.1038/sj.bjc.6605916

[6] MOOK S, KNAUER M, BUENO-DE-MESQUITA JM, RETEL VP, WESSELING J et al. Metastatic potential of T1 breast cancer can be predicted by the 70-gene MammaPrint signature. Ann Surg Oncol 2010; 17, 1406-13. http://dx.doi. org/10.1245/s10434-009-0902-X

[7] HERSCHKOWITZ JI, ZHAO W, ZHANG M, USARY J, MURROW G et al. Breast cancer special feature: comparative oncogenomics identifies breast tumors enriched in functional tumor- initiating cells. Proc Natl Acad Sci U S A 2011 [Epub ahead of print]

[8] SORLIE T, PEROU CM, TIBSHIRANI R, AAS T, GEISLER $S$ et al. Gene expression patterns of breast carcinomas distinguish tumor subclasses with clinical implications. Proc Natl Acad Sci U S A 2001; 98, 10869-74. http: //dx.doi. org/10.1073/pnas.191367098

[9] RUSSNES HG, VOLLAN HK, LINGJAERDE OC, KRASNITZ A, LUNDIN $P$ et al. Genomic architecture characterizes tumor progression paths and fate in breast cancer patients. Sci Transl Med 2010; 2, 38-47.

[10] PEROU CM, SORLIE T, EISEN MB, VAN DE RIJN M, JEFFREY SS et al. Molecular portraits of human breast tumors. Nature 2000; 406, 747-52. http://dx.doi.org/10.1038/ $\underline{35021093}$

[11] GOLDHIRSCH A, WOOD WC, COATES AS, GELBER RD, THURLIMANN B, SENN HJ. Strategies for subtypes - dealing with the diversity of breast cancer: highlights of the St. Gallen International Expert Consensus on the Primary Thrapy 
of Early Breast Cancer 2011. Ann Oncol 2011; 22: 1736-47. http: //dx.doi.org/10.1093/annonc/mdr304

[12] CARDOSO F, PICCART- GEBHART M, VAN 'T VEER L, RUTGERS E, TRANSBIG Consortium. The MINDACT trial the first prospective clinical validation of a genomic tool. Mol Oncol 2007; 1, 246-51. http: //dx.doi.org/10.1016/ j.molonc.2007.10.004

[13] TIAN S, ROEPMAN P, VAN 'T VEER LJ, BERNARDS R, DE SNOO F, GLAS AM. Biological functions of the genesis in the MammaPrint breast cancer profile reflect the hallmarks of cancer. Biomark Insight 2010; 5, 129-38.

[14] VAN 'T VEER LJ, DAI H, VAN DE VIJVER MJ, HE YD, HART AA et al. Gene expression profiling predicts clinical outcome of breast cancer. Nature 2002; 415, 530-36.

[15] TANG G, SHAK S, PAIK S, ANDERSON SJ, CONSTANTINO JP et al. Comparison of the prognostic and predictive utilities of the 21-gene Recurrence Score assay and Adjuvant! for women with node - negative, ER- positive breast cancer: result from NSABP B-14 and NSAP B-20. Breast Cancer Res Treat 2011; 127: 133-42. http://dx.doi.org/10.1007/s10549$\underline{010-1331-\mathrm{Z}}$

[16] PAIK S. Development and clinical utility of a 21-gene Recurrence Score prognostic assay in patients with early breast cancer treated with tamoxifen. Oncologist 2007; 12: 631-35. http: //dx.doi.org/10.1634/theoncologist.12-6-631

[17] HARBECK N, THOMSSEN C. A new look at node- negative breast cancer. Oncologist 2010; 15; 29-38. http: //dx.doi. org/10.1634/theoncologist.2010-S5-29

[18] DESMEDT C, PIETTE F, LOI S, WANG Y, LALLEMAND $\mathrm{F}$ et al. Strong time dependence of the 76- gene prognostic signature for node- negative breast cancer patients in the TRANSBIG multicenter independent validation series. Clin Cancer Res 2007; 13, 3207-14. http: //dx.doi.org/10.1158/ 1078-0432.CCR-06-2765

[19] TAUBE JH, HERSCHKOWITZ JI, KOMUROV K, ZHOU AY, GUPTA $S$ et al. Core epithelial-to-mesenchymal transition interactome gene- expression signature is associated with claudin- low and metaplastic breast cancer subtypes. Proc Natl Acad Sci U S A 2010; 107, 15449-54. http: //dx.doi. org/10.1073/pnas.1004900107

[20] ASCIERTO ML, KMIECIAK M, IDOWU MO, MANJILI R, $\mathrm{ZHAO} Y$ et al. A signature of immune function genes associated with recurrence - free survival in breast cancer patients. Breast Cancer Res Treat 2011. http: //dx.doi.org/10.1007/ $\underline{\text { s10549-011-1470-X }}$

[21] CHANG HY, NUYTEN DS, SNEDDON JB, HASTIE T, TIBSHIRANI R et al. Robustness, scalability, and integration of a wound- response gene expression signature in predicting breast cancer survival. Proc Natl Acad Sci U S A 2005; 102: 3738-43. http: //dx.doi.org/10.1073/pnas.0409462102

[22] DESMEDT C, DI LEO A, DE AZAMBUJA E. Multifactoral approach to predicting resistance to anthracyclines. J Clin Oncol 2011; 29, 1578-86. http: //dx.doi.org/10.1200/ LCO.2010.31.2231

[23] HAIBE-KAINS B, DESMEDT C, ROTHE F, PICCART M, SOTIRIOU C, BONTEMPI G. Computational fuzzy gene expression- based approach improves breast cancer prognostication. Genome Biol 2010; 11: R18. http: //dx.doi. org/10.1186/gb-2010-11-2-r18

[24] www.ncbi.nlm.nih.gov

[25] www.genecards.org

[26] RAY PS, WANG J, QU Y, SIM MS, SHAMONKI JM et al. FOXC1 is a potential prognostic biomarker with functional significance in basal- like breast cancer. Cancer Res 2010; 70(10). http: //dx.doi.org/10.1158/0008-5472.CAN-09$\underline{4120}$

[27] RAY PS, BAGARIA SP, WANG J, SHAMONKI JM, YE X et al. Basal- like breast cancer defined by FOXC1 expression offers superior prognostic value: a retrospective immunohistochemical study. Ann Surg Oncol 2011; Mar 18 [Epub ahead of print]

[28] CAVALLI LR, RIQQINS RB, WANG A, CLARKE R, HADDAD $B R$. Frequent loss of heterozygosity at the interferon regulatory factor - 1 gene locus in breast cancer. Breast Cancer Res Treat 2010; 121: 227-31. http: //dx.doi.org/10.1007/s10549-0090509-8

[29] TESCHENDORFF AE, GOMEZ S, ARENAS A, EL-ASHRY $\mathrm{D}, \mathrm{SCHMIDT} \mathrm{M}$ et al. Improved prognostic classification of breast cancer defined by antagonistic activation patterns of immune response pathway modules. BMC 2010; 10: 604.

[30] RODY A, HOLTRICH U, PUSZTAI L, LIEDTKE C, GAETJE $\mathrm{R}$ et al. T-cell metagene predicts a favorable prognosis in estrogen receptor- negative and HER2 positive breast cancers. Breast Cancer Res 2009; 11, R15. http: //dx.doi.org/10.1186/ bcr2234

[31] TANEI T, SHIMOMURA A, SHIMAZU K, NAKAYAMA T, KIM SJ et al. Prognostic significance of Ki67 index after neoadjuvant chemotherapy in breast cancer. Eur J Surg Oncol 2011; 37, 155-161. http: //dx.doi.org/10.1016/j.ejso.2010.10.009

[32] KIM RG, KIM EK, KIM HA, KOH JS, KIM MS et al. Prognostic significance of molecular subtype in T1N0M0 breast cancer: Korean experience. Eur J Surg Oncol 2011; 37, 629-34. http: //dx.doi.org/10.1016/j.ejso.2011.04.014

[33] YERUSHALMI R, GELMAN KA, LEUNG S, GAO D, CHEANG $\mathrm{M}$ et al. Insulin-like growth factor (IGF-1R) in breast cancer subtypes. Breast Cancer Res Treat 2011 May 15 [Epub ahead of print]

[34] FU P, IBUSUKI M, YAMAMOTO Y, HAYASHI M, MURAKAMI K et al. Insulin- like growth factor-1 receptor gene expression is associated with survival in breast cancer: a comprehensive analysis of gene copy number, mRNA and protein expression. Breast Cancer Res Treat 2011; Jul 12 [Epub ahead of print]

[35] HARTOG H, HORLINGS HM, VAN DER VEGT B, KREIKE B, AJOUAOU A, et al. Divergent effects of insulin -like growth factor- 1 receptor expression on prognosis of estrogen receptor positive versus triple negative invasive ductal breast carcinoma. Breast Cancer Res Treat 2010; Nov 24 [Epub ahead of print]

[36] PEIRO G, ADROVER E, SANCHEZ -TEJADA L, LERMA E, PLANELLES $M$ et al. Increased IGF1R mRNA expression predicts poor survival in immunophenotypes of early breast carcinoma. Mod Pathol 2011; 24, 201-8. http: //dx.doi. org/10.1038/modpathol.2010.191 
[37] MARTINEZ-OUTSCHOORN UE, PRISCO M, ERTEL A, TSIRIGOS A, LIN Z et al. Ketones and actate increase cancer cell "stemness", driving recurrence, metastasis and poor clinical outcome in breast cancer. Cell Cycle 2011; 10, 1271-86. http: //dx.doi.org/10.4161/cc.10.8.15330

[38] HADAD S, IWAMOTO T, JORDAN L, PURDIE C, BRAY $S$ et al. Evidence for biological effects of metformin in operable breast cancer: a pre-operative, window-of-opportunity, randomized trial. Breast Cancer Res Treat 2011; 128, 783-94. http: //dx.doi.org/10.1007/s10549-011-1612-1
[39] TAWFIK K, KIMLER BF, DAVIS MK, FAN F, TAWFIK O. Prognostic significance of Bcl-2 in invasive mammary carcinomas: a comparative clinicopathologic study between triple -negative and non-triple negative tumors. Hum Pathol 2011; Jul 19 [Epub ahead of print]

[40] KORONAKIS N, KARANIKAS G, LAGOUDIANAKIS EE, GROSOMANADIS D, PAPPA A et al. Analysis of clinical and molecular associations of triple negative breast cancers in node- negative patients. Eur J Gynaecol Oncol 2010; 31: 304-7. 